\title{
Glomus intraradices (N.C. Schenck \& G.S. Sm.) C. Walker \& A. Schuessle enhances nutrients uptake, chlorophyll and essential oil contents and composition in Anethum graveolens $\mathbf{L}$.
}

\author{
Weria WEISANY ${ }^{1}$
}

Received October 08, 2017; accepted September 30, 2018.

Delo je prispelo 08. oktobra 2017, sprejeto 30. septembra 2018.

\begin{abstract}
Arbuscular mycorrhizal (AM) fungi are plant-root symbionts whose application in agriculture has been proven its efficiency. However, their application in medicinal plants and their impact on accumulation of essential oils (EO) is still limited. In order to investigate the effect of AM fungi (Glomus intraradices N.C. Schenck \& G.S. Sm.) C. Walker \& A. Schuessle) on nutrients uptake, biomass production, yield components, chlorophyll content, and EO content and composition in dill (Anethum graveolens L.), a field experiment was conducted as randomized complete block design with three replications. This medicinal plant was grown under AM fungi colonization and non-colonization treatments. Plant inoculation by mycorrhiza increased aerial tissues $\mathrm{P}$ and $\mathrm{Fe}$ concentrations. However, $\mathrm{K}, \mathrm{Ca}$, and $\mathrm{Zn}$ concentrations were not affected by AM colonization. The plants inoculated with AM significantly increased plant biomass, chlorophyll content, and EO content by $363 \mathrm{~g} \mathrm{~m}^{-2}, 11.83$ SPAD and $0.683 \%$ in comparison with non-inoculated plants, respectively. Changes in EO composition were found in AMcolonized dill plants. The contents of myristicin, dill-ether and $\mathrm{N}$-dihydrocarvone increased in EO obtained from AMcolonized plants, while AM colonization resulted in a lesser content of $\alpha$-pinene, $\alpha$-phellandrene, limonene, and $\beta$ phellandrene.
\end{abstract}

Key words: arbuscular mycorrhizal fungi; dill; essential oil; medicinal plants; nutrient uptake
IZVLEČEK

\author{
MIKORIZACIJA Z ARBUSKULARNO GLIVO Glomus \\ intraradices (N.C. Schenck \& G.S. Sm.) C. Walker \& A. \\ Schuessle POVEČUJE PRIVZEM HRANIL, \\ KONCENTRACIJO KLOROFILA IN VSEBNOSTI \\ ETERIČNIH OLJ PRI NAVADNEM KOPRU (Anethum \\ graveolens L.)
}

Arbuskularne mikorizne glive (AM) so glivni simbionti večine kopenskih rastlin, tudi mnogih kmetijskih rastlin. Njihov pomen za uspevanje rastlin je potrjen, malo pa je znanega o njihovem vplivu na tvorbo eteričnih olj v zdravilnih rastlinah. $\mathrm{Z}$ namenom analize vplivov okužbe koreninskega sistema $\mathrm{Z}$ AM na tvorbo sekundarnih metabolitov smo analizirali navadni koper (Anethum graveolens L.) z glivo Glomus intraradices N.C. Schenck \& G.S. Sm.) C. Walker \& A. Schuessle $v$ poljskem poskusu organiziranem kot naključno zasnovani komplet $\mathrm{s}$ tremi ponovitvami. Analizirali smo absorpcijo hranil, proizvodnjo biomase, deleže pridelka, vsebnost klorofila in vsebnost eteričnih olj ter kemijsko sestavo nadzemnih delo rastline. Inokulacija rastlin z AM je povečala koncentracije $\mathrm{P}$ in $\mathrm{Fe} \mathrm{v}$ nadzemnih tkivih, nismo pa ugotovili značilnih sprememb $\mathrm{v}$ koncentracijah $\mathrm{K}, \mathrm{Ca}$ in $\mathrm{Zn}$. Rastline, inokulirane z AM, so imele bistveno bujnejšo rast, večjo vsebnost klorofila in eteričnih olj $\mathrm{V}$ primerjavi $\mathrm{Z}$ neinokuliranimi rastlinami. Pri inokuliranih rastlinah smo ugotovili tudi spremembe $\mathrm{v}$ sestavi nabora eteričnih olj, povečana je bila količina miristicina, koprovega etra in $\mathrm{N}$ dihidrokarvona, zmanjšala pa se je količina $\alpha$-pinena, $\alpha$ felandrena, limonena, in $\beta$-felandrena.

Ključne besede: arbuskularna mikoriza; navadni koper; eterična olja; zdravilne rastline; privzem hranil

\section{INTRODUCTION}

Medicinal plants play major roles in human health services worldwide (Weisany et al., 2015), and herbal medicine is gaining importance at global level
(Wondimu et al., 2007). Essential oils (EO) constituents of the medicinal and aromatic plants are most frequently used as a source of new bioactive molecules. The EOs

Department of Horticulture and Crop Science, Science and Research Branch of the Islamic Azad University, Tehran, Iran. *corresponding author:weria.wisany@gmail.com 
are abundant in flowers, leaves, seeds, and are usually isolated via hydro-distillation, cold pressing methods (Edris, 2007). Their main active components are: carvone, carvacrol, eugenol, myristicin and apiole (Duke, 2001), although their mechanism of action is still poorly understood (Burt, 2004; Calo et al., 2015).

Dill (Anethum graveolens L.) is important essential oils producing plant. Myristicin and apiole in A. graveolens EO components are applied as a toxin and repellent to growing larvae and adults of Tribolium castaneum (Chaubey, 2007). Furthermore, the essential oils from its fruits and shoots are used in pharmacology as well as food and in soap industries.

It is well accepted that suitable use of irrigation and chemical fertilizers improve yield and quality of oil in aromatic plants (Singh and Randhawa, 1990; Tiwari and Banafar, 1995). However, for sustainable agriculture, traditional agriculture practices, including heavy fertilizer input are adverse owing to their long-lasting impact on the ground water quality (Yao et al., 2001). The alternative for sustainable plant production system to ensure increased productivity is to limit chemical input along with bio-inoculants so as to augment nutrient uptake by plants (Bethlenfalvay and Linderman, 1992).

Arbuscular mycorrhizal (AM) fungi can result in beneficial effects on soil and plant ecosystem such as improving soil structure (Rillig and Mummey, 2006; Bedini et al., 2009) and influencing plant nutrient uptake (Smith and Read, 2008; Clark and Zeto, 2000) and influencing major element cycles (for example, carbon, phosphorus and nitrogen) (Fitter et al., 2011). It is well accepted that AM fungi can improve the uptake of micronutrients and other mineral nutrients with low mobility including Fe (Clark and Zeto, 2000), Zn (Weisany et al., 2016a) and Mn (Weisany et al., 2016b). Utilizing management practices of AM fungi associated with promote effects of AM fungi on phosphorus uptake, growth, and grain yield of crops (Sohrabi et al., 2012b; Arihara and Karasawa, 2000; Karasawa et al., 2002). Previous studies have shown that different species and isolates of Glomus had various effects on mycorrhizal plants (Sohrabi et al., 2012a,b).
AM fungi promote the accumulation of effective ingredients of medicinal plants, which has become a hot area of research lately (Raei and Weisany, 2013). AM fungi application may provide a natural regulation mechanisms and ecological method to increase the accumulation of secondary metabolites in medicinal plants, because it contributes to a reduction of need to apply chemical fertilizers and development of sustainable agriculture (Pedone-Bonfim et al., 2013). AM fungi can affect the production of active ingredients in medicinal and aromatic plants (Karagiannidis et al., 2011), resulting from a better nutritional condition or by means of protecting the host from the pathogenic fungi (Volpin et al., 1994). Symbiosis between plants and AM fungi can increase the accumulation of several secondary metabolites in medicinal plants which plays important roles in treating human diseases (Weisany et al., 2015). The influence degree of different AM fungi varies among the medicinal plants. The scientific reports suggest the improved production of EO in coriander and dill inoculated by Glomus fasciculatum (Taxt.) Gerd.ec Trappe or G. macrocarpum Tul. \& C. Tul. (Kapoor et al., 2002a, b), in mint inoculated by G. fasciculatum or a suite of AM fungi (Freitas et al., 2004), in oregano and dill inoculated by Glomus mosseae (T.H. Nicolson \& Gerd.) Gerd. \& Trappe 1974 (Khaosaad et al., 2006; Weisany et al., 2015), and in annual wormwood colonized by G. faciculatum (Kappoor et al., 2007; Chaudhary et al., 2008).

While AM colonization can increase the EO contents of medicinal plants, it is not clear whether the composition of the EO could be affected. Therefore, the overall aim of the present study is to investigate the fact that whether AM fungi can provide an effective and natural way of improving the growth, chlorophyll content, nutrient uptake, and EO content and composition in dill plants. More specifically, through testing two hypotheses we attempted to evaluate whether the composition of the secondary metabolites in dill are affected by AM fungi inoculation. The first hypothesis is that AM fungi enhance chlorophyll content and nutrient uptake in dill and this, in turn, increase the plant production. The second hypothesis is that symbiosis between plant and AM fungi boosts the accumulation of several secondary metabolites in dill.

\section{MATERIALS AND METHODS}

\subsection{Experimental design}

A field experiment was conducted in the Agriculture and Natural Resources Research Center of Kurdistan Province in 2014. Soil samples were taken from depths of $0-10 \mathrm{~cm}$ and $10-25 \mathrm{~cm}$ and mixed, using a soil auger. These samples were collected in spring from 8 points of experimental area. All soil samples were air dried at laboratory for 7 days and then crushed and sieved through a $2 \mathrm{~mm}$ sieve to determine the chemical composition (Rao, 1993). The texture of the soil was sandy clay loam. Different chemical and physical 
properties of soils are presented in Table 1. The experiment carried out as randomized complete block design with three replications. The medicinal plant studied in this research was dill (Anethum graveolens L.). It was applied as a colonized and non-colonized plant by arbuscular mycorrhizal fungi. The medicinal plant was managed according to the organic farming practices without using pesticides or fertilisers. Seeds were sown in plots $(4 \times 5 \mathrm{~m})$, each with 8 rows. Three seeds were sown by hand on the eastern side of the ridges in each hole being at a $10-\mathrm{cm}$ distance from another hole. After emergence, the seedlings were thinned and one plants was kept in each hole. Plots of non-colonized seeds were sown first in order to avoid AM cross contamination.

Table 1: Some physical and chemical properties of the soil of experimental area

\begin{tabular}{|c|c|c|c|c|c|c|c|c|c|c|}
\hline \multirow[t]{2}{*}{ Texture } & Organic carbon $\%$ & $\mathrm{pH}(1: 2.5)$ & $\mathrm{K}$ & $\mathrm{P}$ & $\mathrm{Ca}$ & $\mathrm{Na}$ & $\mathrm{Zn}$ & $\mathrm{Mn}$ & $\mathrm{Fe}$ & $\mathrm{Cu}$ \\
\hline & \multicolumn{10}{|c|}{$\left(\mathrm{mg} \mathrm{kg}^{-1}\right.$ soil $)$} \\
\hline $\begin{array}{c}\text { Sandy clay } \\
\text { loam }\end{array}$ & 1.14 & 7.12 & 131 & 12.2 & 1150.1 & 450.2 & 0.476 & 7.054 & 6.97 & 0.826 \\
\hline
\end{tabular}

Thirty grams of soil inoculum (100 endomycorrhizal spore/10 g soil) along with $300 \mathrm{mg}$ of chopped $G$. intraradices -colonized Zea mays L. roots were added to each plot at sowing time just below the seeds. The AM fungus ( $G$. intraradices) was obtained from the culture collection of Tabriz University, Tabriz, Iran (Weisany et al., 2015).

\subsection{Arbuscular mycorrhizal fungi colonization}

Five plants from each plot were randomly collected at 95 days after AM fungi inoculation. The root samples were extracted by using a cylindrical corer $(10 \mathrm{~mm})$. The roots were washed, cut into about $1 \mathrm{~cm}$ long pieces and mixed thoroughly. The staining procedure was applied according to Phillips and Hayman (1970) with the modified parameters for the present study. The roots were cut into small pieces $(1 \mathrm{~cm})$ and placed in a beaker $(10 \% \mathrm{KOH})$ for $60 \mathrm{~min}$ in a water bath at $65{ }^{\circ} \mathrm{C}$. The roots were then rinsed with tap water and acidified with $5 \%$ lactic acid at room temperature for $12 \mathrm{~h}$. Finally, they were stained by a solution containing $875 \mathrm{ml}$ of lactic acid, $63 \mathrm{ml}$ of glycerin, $63 \mathrm{ml}$ of tap water, and $0.1 \mathrm{~g}$ of fuchsine acid for $30 \mathrm{~min}$ at $70{ }^{\circ} \mathrm{C}$ and were then de-stained by lactic acid for $15 \mathrm{~min}$. Afterwards, root segments were mounted onto slides and examined at 100-400 magnification under a Nikon YS100 microscope. Beneath the glass slide an acetate film with 10 thin lines was adapted. At crossing points between roots and lines, each point that had an infection was recorded and the number of infections was expressed as percentage (Weisany et al., 2015). The percentage of AM root colonization was calculated by the following equation (McGonigle et al., 1990):

Root colonization $(\%)=$ (number of root segments colonized/number of root segments studied) $\times 100$

\subsection{Mineral nutrient analysis}

The dry ash method was used (Jones and Case, 1990) to measure different elements in dill. In this way, the aerial tissues of plants were dried in an oven at $70^{\circ} \mathrm{C}$. Five plants from the each plot were randomly harvested. Subsequently, $1 \mathrm{~g}$ of dry matter was transferred into ceramic vessels and was slowly subjected to $500{ }^{\circ} \mathrm{C}$ in the oven. The final product was a white ash. White ash was cooled in room temperature and then $20 \mathrm{ml} 1 \mathrm{~N} \mathrm{HCl}$ was added to each sample, followed by the sand bath for 30 minutes. The samples were elutriated in a $100 \mathrm{ml}$ volumetric balloon (Cottenie, 1980). Having provided plant extracts, the concentrations of calcium $(\mathrm{Ca})$ and potassium $(\mathrm{K})$ were measured via flame photometer (Model 410, Corning, Halstead, UK). Iron (Fe) and zinc (Zn) concentrations were measured by atomic absorption spectrometer (Shimadzu AA6600) (Jones 1972). Plant phosphorous was gauged through the yellow method, in which, vanadate-molybdate (Tandon et al., 1968) was employed as an indicator. $P$ concentration was determined at $430 \mathrm{~nm}$, using a spectrophotometer apparatus (Shimadzu, UV3100).

\subsection{Plant growth measurements and chlorophyll content}

Ten plants from each plot were randomly harvested after seed maturation. In the sampling plots, the randomly chosen plants from the each treatment were harvested along with complete roots, and the plant biomass (dry mass) was recorded (Weisany et al., 2015). Ten indiscriminately selected plants at full maturity stage in each plot were cut, and the plant height and yield components were defined.

Chlorophyll status of dill plants was evaluated in each plot by SPAD analysis (SPAD 502, Minolta Ltd. Osaka, Japan). SPAD measurements were performed at flowering stage, and the mean of three random SPAD measurements on the middle part of the leaf blade was recorded (Weisany et al., 2015).

\subsection{Essential oil extraction}

Acta agriculturae Slovenica, 111 - 2, september 2018 
At the beginning of flowering, aerial tissues of dill were harvested from $1 \mathrm{~m}^{2}$. The EOs were extracted by hydrodistillation in $500 \mathrm{ml}$ of water, using a Clevenger apparatus for $2 \mathrm{~h}$. The distillate was extracted using diethyl-ether as solvent $(1 / 1, \mathrm{v} / \mathrm{v})$ and drying the sample over anhydrous sodium sulphate. The organic layer was then concentrated at $35^{\circ} \mathrm{C}$ by a Vigreux column and the EO was stored at $4{ }^{\circ} \mathrm{C}$ prior to analysis (Weisany et al., $2016 \mathrm{~b}$ ). The percentage of EO content was measured in volume/100 $\mathrm{g}$ dry mass basis.

\subsection{Gas chromatography-mass spectrometry}

Gas chromatography (GC) analysis was performed by means of a trace GC ultra-gas chromatograph coupled with a TSQ quantum tandem mass spectrometer upgraded to the XLS configuration. A DuraBrite IRIS ion source with pre-filter was installed so as to improve the performance of the spectrometer. The system was equipped with a triplus autosampler (Thermo Electron Corporation, Waltham, MA). The injection volume was $1 \mu \mathrm{l}$, post injection dwell time $4 \mathrm{sec}$, and tray temperature $7{ }^{\circ} \mathrm{C}$. GC separation was done on a $30-\mathrm{m}$ VF-WAXms capillary column with an internal diameter of $0.25 \mathrm{~mm}$ and a film thickness of $0.25 \mu \mathrm{m}$ (Varian, Inc. USA). Temperature programming was as follows: $40{ }^{\circ} \mathrm{C}$ held for $4 \mathrm{~min}$ after injection and $6^{\circ} \mathrm{C} \mathrm{min}^{-1}$ up to $250{ }^{\circ} \mathrm{C}$ held for $5 \mathrm{~min}$. Injection parameters were as follows: split injection, split ratio of 100:1, inlet temperature of $250{ }^{\circ} \mathrm{C}$, carrier gas being helium 5.5 , and

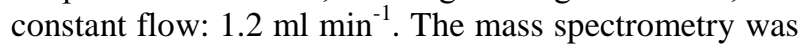
used in scan mode in the range of $40-400 \mathrm{~m} / \mathrm{z}$ with a scan time of $0.2 \mathrm{sec}$. The ionization mode was electron impact (EI), and the source temperature was kept at 250 ${ }^{\circ} \mathrm{C}$ (Perini et al., 2014).

\subsection{Statistical Analysis}

Analysis of variance was carried out, using SAS version 9.1 (SAS Institute Inc., Cary, NC, USA) (SAS Institute Inc. 1988). Means of the treatments were compared through orthogonal comparisons. The data showed normal distribution and no transformation has ben done.

\section{RESULTS AND DISCUSSION}

\subsection{AM colonization}

Arbuscular mycorrhiza colonization was observed in inoculated plants and root samples. The percentage of mycorrhizal root colonization was significantly greater in all the treatments of plant colonization with mycorrhiza in comparison with non-inoculated control plants (Table 2).

Table 2: Root AM colonization, growth and yield components, chlorophyll, mineral nutrient and essential oil contents of dill inoculated (+AM) and non-inoculated with arbuscular mycorrhiza (-AM)

\begin{tabular}{|c|c|c|c|}
\hline Parameters & & & \\
\hline & $-\mathrm{AM}$ & $+\mathrm{AM}$ & $\operatorname{Pr}>\mathrm{F}$ \\
\hline AM colonization $(\%)$ & $0.00 \pm 0.00$ & $80.6 \pm 6.568$ & $0.0056 * *$ \\
\hline Phosphorous (mg kg ${ }^{-1} \mathrm{DM}$ ) & $13.78 \pm 0.016$ & $14.29 \pm 0.025$ & $0.0003 * *$ \\
\hline Zinc $\left(\mathrm{mg} \mathrm{kg}^{-1} \mathrm{DM}\right)$ & $0.449 \pm 0 . .009$ & $0.458 \pm 0.001$ & $1.0000 \mathrm{~ns}$ \\
\hline Iron ( $\left.\mathrm{mg} \mathrm{kg}^{-1} \mathrm{DM}\right)$ & $1.131 \pm 0.338$ & $1.946 \pm 0.499$ & $0.0367 *$ \\
\hline Potassium ( $\left.\mathrm{mg} \mathrm{kg}^{-1} \mathrm{DM}\right)$ & $255.45 \pm 33.80$ & $320.05 \pm 21.33$ & $0.3620 \mathrm{~ns}$ \\
\hline Calcium (mg kg $\left.{ }^{-1} \mathrm{DM}\right)$ & $622.0 \pm 20.78$ & $685.5 \pm 53.98$ & $0.1959 \mathrm{~ns}$ \\
\hline Plant height $(\mathrm{cm})$ & $43.00 \pm 5.291$ & $50.66 \pm 7.310$ & $0.3995 \mathrm{~ns}$ \\
\hline Number of branches/plant & $6.66 \pm 0.333$ & $7.660 \pm 0.666$ & $0.4226 \mathrm{~ns}$ \\
\hline Number of umbels/plant & $6.67 \pm 0.333$ & $7.33 \pm 0.881$ & $0.4226 \mathrm{~ns}$ \\
\hline Number of umbelet/plant & $94.66 \pm 3.179$ & $109.33 \pm 5.456$ & $0.3570 \mathrm{~ns}$ \\
\hline Root length $(\mathrm{cm})$ & $10.01 \pm 0.577$ & $14.50 \pm 0.866$ & $0.0701 \mathrm{~ns}$ \\
\hline Plant biomass $\left(\mathrm{g} \mathrm{m}^{-2}\right)$ & $205.33 \pm 3.289$ & $363.33 \pm 26.193$ & $0.0204^{*}$ \\
\hline Chlorophyll (SPAD) & $6.90 \pm 0.2645$ & $11.83 \pm 0.2962$ & $0.0121^{*}$ \\
\hline Total essential oil (\%) & $0.377 \pm 0.000$ & $0.683 \pm 0.000$ & $0.0251 *$ \\
\hline
\end{tabular}

+AM, -AM: inoculated and non-inoculated with arbuscular mycorrhiza, respectively.

Results are the mean of three replications $\pm \mathrm{SD}$. NS, $*$ and $* *$, non-significant and significant at $\mathrm{P} \leq 0.05$ and $\mathrm{P} \leq 0.01$, respectively.

\subsection{Mineral nutrient uptake}

Results of this study indicated that plant colonization with AM enhanced the aerial tissues $\mathrm{P}$ concentration of dill, compared with control plants (Table 2). So, the inoculated dill with $G$. intraradices had the most (14.29 mg $\left.\mathrm{kg}^{-1} \mathrm{DM}\right)$, but non-inoculated plants had the least (13.78 $\left.\mathrm{mg} \mathrm{kg}^{-1} \mathrm{DM}\right) \mathrm{P}$ concentrations (Table 2). Mycorrhization of target plant provides a better nutrient 
status by the wide extra-radical mycelium of AM that equips the plant roots with a more surface area for uptake of nutrients and water (Jefferies et al., 2003).

AM fungal hyphae can transfer immobile $\mathrm{P}$ resources to the roots from a long distance (over centimeters) and therefore, play an even more important role in P uptake by their host plants than what was previously taken for granted (Richardson et al,. 2011, Weisany et al., 2016a).

The colonization of dill with $G$. intraradices increased Fe concentration to $1.946 \mathrm{mg} \mathrm{kg}^{-1} \mathrm{DM}$, whereas the noninoculated plants had the least $\mathrm{Fe}$ concentration (1.131 $\left.\mathrm{mg} \mathrm{kg}^{-1} \mathrm{DM}\right)$. However, there was no significant difference between inoculated and non- inoculated plants in terms of $\mathrm{K}, \mathrm{Ca}$ and $\mathrm{Zn}$ concentration (Table 2). The increased utilization of soil volume is especially important in the uptake of less mobile nutrients such as $\mathrm{P}$ and $\mathrm{Fe}$ (Smith and Read, 2008). Increased uptake of Fe by mycorrhizal fungi may be in part due to production of siderophores that specifically chelate $\mathrm{Fe}$ (Shende and Rai, 2010). AM fungi moderate the ion balance in the plant that affecting the availability of mineral nutrients in plant tissues (Bermudez and Azcon, 1996).

\subsection{Growth and yield components}

Dill plant biomass was effected by AM colonization, so that the inoculated plants with $G$. intraradices had more (363.3 $\mathrm{g} \mathrm{m}^{-2}$ ) compared with non-inoculated plants (205.3 $\mathrm{g} \mathrm{m}^{-2}$ ) plant biomass. However, plant height, number of branches per plant, number of umbels per plant, number of umbelets per plant and root length of dill were not substantially affected by AM inoculation (Table 2).

Our previous studies have revealed that different species and isolates of Glomus increased plant height, total dry mass and root and aerial tissues dry mass of chickpea (Sohrabi et al., 2012a,b). The improvement of plant growth was also observed in coriander (Coriandrum sativum L.) by colonization of AM and application of phosphorus (Farahani et al., 2008). The results of the present study are consistent with these reports. The increase in growth can be attributed to improved $\mathrm{P}$ and Fe nutrition in these treatments (Table 2). In the current research, plant inoculation with AM augmented the growth of dill, supporting the observation that mycorrhizal plants obtain more nutrients. Furthermore, $\mathrm{AM}$ are able to share nutrients via an underground network of hyphal connections linking individuals within and between species (Simard et al., 2003).

The positive influence of $\mathrm{P}$ and $\mathrm{Fe}$ on growth and yield has been reported for many plants, including those with medicinal value (Naguib et al., 2007). The Fe element plays roles either as functional or structural co-factors or as the metal components of different enzymes
(Marschner, 1995). Inoculation of plant by AM fungi results in higher growth and yield, since it offers an opportunity to optimize the rate of photosynthesis via improved uptake of $\mathrm{P}$ and $\mathrm{Fe}$ nutrients. Therefore, AM fungi provide balanced nutrition to the host plants, leading to increased growth and yield.

\subsection{Chlorophyll content}

Chlorophyll content in dill leaves was markedly influenced by inoculation with AM. In general, inoculated plants with $G$. intraradices had significantly more chlorophyll (11.83 SPAD) than the noninoculated plants $(6.90$ SPAD) (Table 2). The association of AM fungi with the roots of dill plants influence $\mathrm{Fe}$ uptake (Table 2). The Fe plays an important role in various biochemical and physiological processes, such as chlorophyll synthesis, photosynthetic transport, respiration, nitrate reduction and $\mathrm{N}_{2}$ fixation (Robinson and Postgate, 1980). The obtained AMmediated higher chlorophyll content in dill leaves may be due to improved nutrient uptake by this plant, especially that of Fe. These findings are in agreement with those previously found by Mathur and Vyas (2000). They discovered that root colonization with AM increased chlorophyll synthesis. The contribution of $\mathrm{AM}$ fungi and the roots of dill plant influences $\mathrm{Fe}$ acquisition that has poor mobility rates. Fe is an integral component of the chlorophyll molecule (Taiz and Zeiger, 2004).

\subsection{Essential oil yield and composition}

Inoculation of plant with AM fungi considerably influenced EO yield. AM inoculation noticeably enhanced the total EO yield in dill aerial tissues (Table 2). The effect of AM fungi in increasing the production of EO has been reported in some of medicinal plant species (Khaosaad et al., 2006; Copetta et al., 2006; Chaudhary et al., 2008, Weisany et al., 2015). Karagiannidis et al., (2011) obtained similar results in their study on three AM fungi colonization that increased the nutrient concentration, plant growth and EO yield of oregano and mint plants. The boosted EO production is the outcome of enhanced shoot fresh mass (Subrahmanyam et al., 1992; Piccaglia et al., 1993). Kapoor et al. (2007) also noticed that plant inoculation with AM enhances the number of glandular trichomes of Artemisia апnиа L. and, as a consequence, increases artemisinin content in leaves. This bigger number of glands could be related to variation in the hormonal profile of plants due to enhanced amounts of auxins, cytokinins and gibberellins in plants inoculated with AM (Torelli et al., 2000). Additionally, inorganic P concentration can influence the biosynthesis of EO in the plants (Loomis and Corteau, 1972). In the present research, AM fungi improved the absorption of $\mathrm{P}$ in plants. P element may play a direct role in increasing 
the content of secondary metabolites (Abu-Zeyad et al., 1999). The same results were found by Kapoor et al. (2004) in their study on the accumulation of EO in fennel. The present findings concur with these conclusions, because a significant positive correlation between EO synthesis and shoot $\mathrm{P}$ concentrations was found for dill.

Photosynthesis of mycorrhizal plants can increase due to an increased plant chlorophyll content and by the drain of carbon, as a consequence of Calvin cycle activation and higher production of primary metabolites that act as precursors for secondary metabolism (Kaschuk et al., 2009). Gas chromatography (GC) analysis of EO composition showed that dill-apiole was the main component in all treatments and its amount varied among the treatments (Table 3, Fig 1). The second main component of the EO was carvone. The results indicated that inoculation of dill with AM increased myristicin, dill-ether and N-dihydrocarvone contents in plant (Table 3 ). These findings are similar with those of Karagiannidis et al. (2011). Variation in EO composition due to AM colonization (Table 3) maight be related to the nutrition of plants. The accumulation of flavonoids (Larose et al., 2002), phytoalexins (Yao et al., 2003), cyclohexanone derivatives and apocarotenoids (Fester et al., 2002; Vierheilig et al., 2000a,b), triterpenoids (Akiyama and Hayashi, 2002) and phenolic compounds (Devi and Reddy, 2002) in plants inoculated by AM fungi has been previously reported. AM fungi colonization of Salvia officinalis L. changes EO composition, and improves the relative amounts of 1,8-cineole, bornylacetate, $\alpha$-thujones and $\beta$-thujones (Geneva et al., 2010). The mechanisms by which AM fungi changes the production of EO are not clear, but they are possibly associated with improved nutrition.

Table 3: Chemical composition (\% of essential oil) of essential oils of dill shoots inoculated (+AM) and uninoculated with arbuscular mycorrhiza (-AM)

\begin{tabular}{|c|c|c|c|c|}
\hline \multirow[t]{2}{*}{ Compounds (Synonymous) } & \multicolumn{2}{|c|}{ Dill } & \multicolumn{2}{|r|}{ Confirmed by } \\
\hline & -AM & $+\mathrm{AM}$ & $\mathrm{Pr}>\mathrm{F}$ & \\
\hline$\alpha$-pinene & 0.15 & 0.11 & $0.2458 \mathrm{~ns}$ & STD, MS \\
\hline$\alpha$-phellandrene & 2.45 & 2.14 & $0.0011 * *$ & STD, MS \\
\hline Limonene & 4.22 & 3.18 & $0.0001 * *$ & STD, MS \\
\hline$\beta$-phellandrene & 0.47 & 0.39 & $0.0034 * *$ & RI, MS \\
\hline Dill_ether (3,9-epoxy-1-p-menthene; anethofuran) & 0.60 & 0.70 & $0.2879 \mathrm{~ns}$ & RI, MS \\
\hline N-dihydrocarvone (trans-dihydrocarvone) & 4.80 & 5.99 & $0.0011 * *$ & STD, MS \\
\hline Iso-dihydrocarvone (cis-dihydrocarvone) & 10.07 & 11.66 & $0.0002 * *$ & STD, MS \\
\hline Carvone & 26.05 & 23.17 & $0.0001 * *$ & STD, MS \\
\hline Neoiso-dihydrocarveol & 0.41 & 0.43 & $0.3349 \mathrm{~ns}$ & STD, MS \\
\hline Iso-dihydrocarveol & 0.73 & 0.69 & $0.2381 \mathrm{~ns}$ & STD, MS \\
\hline Trans-carveol & 0.11 & 0.10 & $1.0000 \mathrm{~ns}$ & STD, MS \\
\hline Isopiperitenone & 0.05 & 0.05 & $1.0000 \mathrm{~ns}$ & RI, MS \\
\hline Cis-carveol & 0.08 & 0.07 & $0.2879 \mathrm{~ns}$ & STD, MS \\
\hline Thymol & 0.02 & 0.09 & $0.0056^{* *}$ & STD, MS \\
\hline Carvacrol & 0.15 & 0.14 & $0.6560 \mathrm{~ns}$ & STD, MS \\
\hline Elemicin & 0.24 & 0.24 & $1.0000 \mathrm{~ns}$ & RI, MS \\
\hline Myristicin & 0.74 & 1.05 & $0.0006 * *$ & STD, MS \\
\hline Dill_apiole & 48.57 & 49.75 & $0.0001 * *$ & RI, MS \\
\hline
\end{tabular}

STD, $\overline{\mathrm{MS}}=$ confirmed by injection of Standard and by Mass Spectra library; RI, MS = confirmed by n-alkanes Retention Index by Mass Spectra library;

+AM, -AM: inoculated and non-inoculated with arbuscular mycorrhiza, respectively.

NS, $*$ and $* *$, non-significant and significant at $P \leq 0.05$ and $P \leq 0.01$, respectively. Five plants from each plot were randomly collected.

The results of the present research showed that inoculation of plant with AM decreased contents of $\alpha$ pinene, $\alpha$-phellandrene, limonene, and $\beta$-phellandrene in dill plant (Table 3). Most presumably these variations are due to changes in the synthesis pathways and the role of EO in plant physiology. AM colonization significantly increased activities of enzymes related to secondary metabolism. Among enzymes such as chalcone synthase and chalcone isomerase, the key enzymes in the synthesis of flavonoids, and phenylalanine ammonia-lyase (PAL) that catalyzing the deamination of phenylalanine (Ibrahim and Jaafar, 2011) provide precursors for the synthesis of secondary metabolites. The AM fungi also effects cytological changes in the host plant, such as an increase in the number of plastids and mitochondria, leading to the activation of the tricarboxylic acid cycle and the plastid biosynthetic pathways and the increase in the production of primary and secondary metabolites (Lohse et al., 2005, Strack and Fester, 2006). 


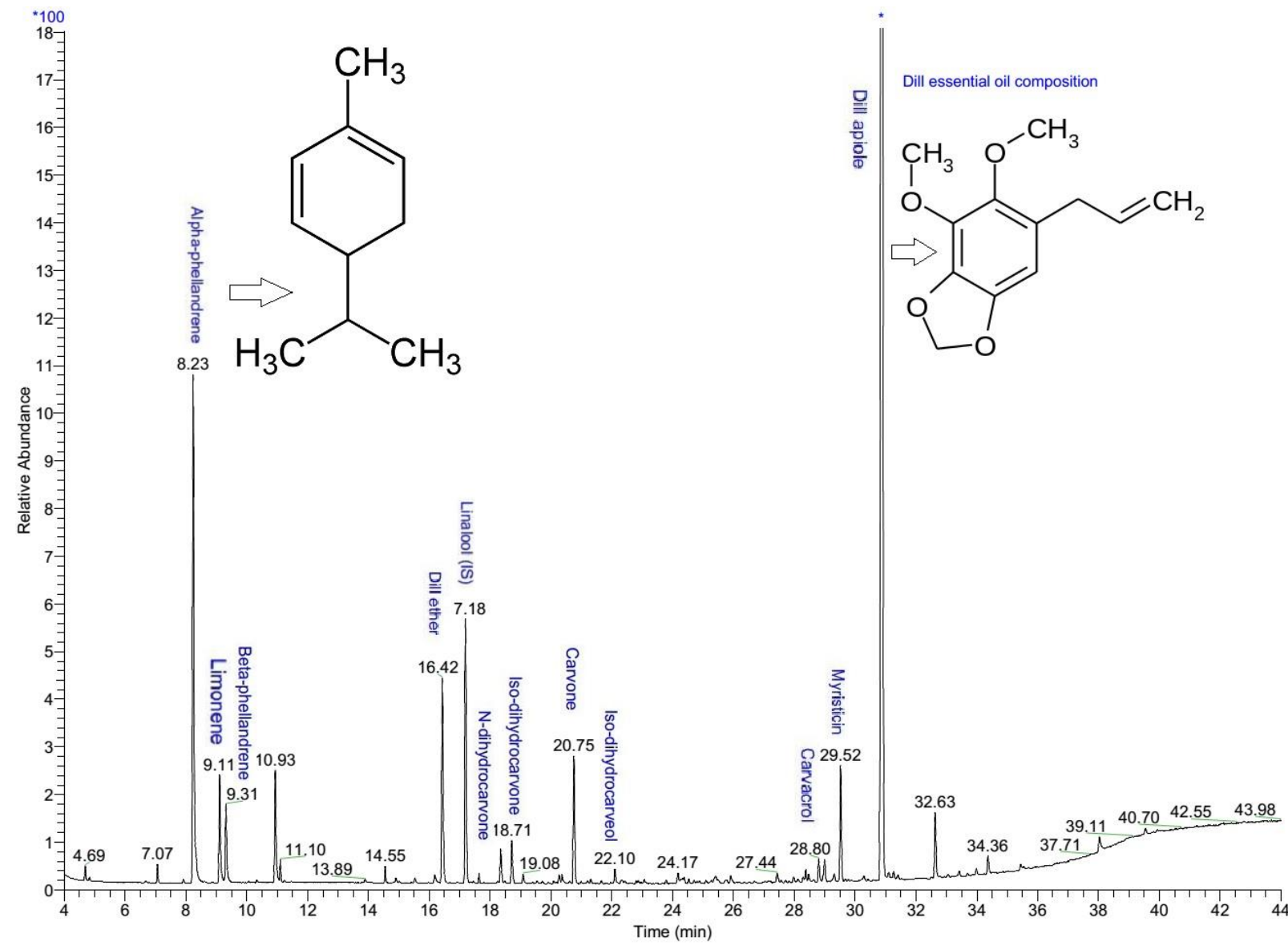

Figure 1: Anethum graveolens L. essential oil chromatogram carried out using a gas chromatograph mass spectrometry. Essential oils were obtained from inoculated with arbuscular mycorrhiza (Glomus intraradices) plant.

\section{DISCUSSIONS}

The study showed that inoculation of dill plant with AM improved mineral nutrition of plant in comparison with non- AM inoculated plants. Increases in growth and chlorophyll content were observed in AM colonized plants. When plant species are inoculated with AM fungi, it is concluded that yield benefits occur as a result of complementary use of resources by the plants. A. graveolens L. EO yield was enhanced in inoculated plants with AM fungi. Aerial tissues EO composition of dill was affected by colonization with AM. Our contribute to the expansion of effective organic and sustainable methods for the cultivation of medicinal plants. Further study in mycorrhizal technology is needed to develop the sustainability of the commercial cultivation of medicinal plants.

\section{ACKNOWLEDGEMENTS}

We would like to thank the research administrators of the University of Tabriz for their financial support. Thanks also to Fondazione Edmund Mach di San
Michele all'Adige, Dr. Urška Vrhovšek, Cesare Lotti and Hamed Hajee for their scientific help. 


\section{REFERENCES}

Abu-Zeyad, R., Khan, A.G., Khoo, C. (1999). Occurrence of arbuscular mycorrhiza in Castanospermum australe A. Cunn. and C. Fraser and effects on growth and production of castanospermine. Mycorrhiza, 9, 111-117.

Akiyama, K., Hayashi, H. (2002). Arbuscular mycorrhizal fungus- promoted accumulation of two new triterpenoids in cucumber roots. Bioscience, Biotechnology, and Biochemistry, 66, 762-769. doi:10.1271/bbb.66.762

Al-Karaki, G.N., Clark, R.B. (1998). Growth, mineral acquisition, and water use by mycorrhizal wheat grown under water stress. Journal of Plant Nutrition, 21, 263-276. doi:10.1080/01904169809365401

Arihara, J., Karasawa, T. (2000). Effect of previous crops on arbuscular mycorrhizal formation and growth of succeeding maize. Soil Science and Plant Nutrition, 46, 43-51. doi:10.1080/00380768.2000.10408760

Bedini, S., Pellegrino, E., Avio, L., Pellegrini, S., Bazzoffi, P., Argese, E., Giovannetti, M. (2009). Changes in soil aggregation and glomalin-related soil protein content as affected by the arbuscular mycorrhizal fungal species Glomus mosseae and Glomus intraradices. Soil Biology and Biochemistry, $\quad 41, \quad$ 1491-1496. doi:10.1016/j.soilbio.2009.04.005

Bermudez, M., Azcon, R. (1996). Calcium uptake by alfalfa as modified by a mycorrhizal fungus and liming. Symbiosis, 20, 175-184.

Bethlenfalvay, G.J., Linderman. R.G. (1992). Mycorrhizae in Sustainable Agriculture. USA: ASA Special Publication 54. ISBN 0-89118- 112-1.

Burt, S. (2004). Essential oils: Their antibacterial properties and potential applications in foods-A review. International Journal of Food Microbiology, $\quad 94, \quad 223-253$. doi:10.1016/j.ijfoodmicro.2004.03.022

Calo, J.R. Crandall, P.G. O’Bryan, C.A. Ricke, S.C. (2015). Essential oils as antimicrobials in food systems-A review. Food Control, 54, 111-119. doi:10.1016/j.foodcont.2014.12.040

Chaubey, M.K. (2007). Insecticidal activity of Trachspermum ammi (Umbelliferae), Anethum graveolens (Umbelliferae) and Nigella sativa (Ranunculaceae) essential oils against storedproduct beetle Tribolium castaneum Herbst Coleoptra: Tenebrionidae. African Journal of Agricultural Research, 2, 596-600.
Chaudhary, V., Kapoor, R., Bhatnagar, A.K. (2008). Effectiveness of two arbuscular mycorrhizal fungi on concentrations of essential oil and artemisinin in three accessions of Artemisia annua L. Applied Soil Ecology, 40, 174-181. doi:10.1016/j.apsoil.2008.04.003

Clark, R.B., Zeto, S.K. (2000). Mineral acquisition by arbuscular mycorrhizal plants. Journal of Plant Nutrition, 23, 867-902. doi:10.1080/01904160009382068

Copetta, A., Lingua, G., Berta, G. (2006). Effects of three AM fungi on growth, distribution of glandular hairs, and essential oil production in Ocimum basilicum L. var: Genovese. Mycorrhiza, 16, 485494. doi:10.1007/s00572-006-0065-6

Cottenie, A., (1980). Methods of Plant Analysis. In: Soil and Plant Testing. FAO Soils Bulletin 38/2. Pp 64100.

Devi, M.C., Reddy, M.N., (2002). Phenolic acid metabolism of groundnut (Arachis hypogaea L.) plants inoculated with VAM fungus and Rhizobium. Plant Growth Regulation, 37,151-156. doi:10.1023/A:1020569525965

Duke, J.A. (2001). Handbook of Medicinal Herbs. CRC Press LLC, USA, pp. 42.

Edris, A. E. (2007). Pharmaceutical and therapeutic potentials of essential oils and their individual volatile constituents: a review. Phytotherapy Research, 21, 308-323. doi:10.1002/ptr.2072

Farag, R.S., Daw, Z.Y., Abo-Raya, S.H. (1989). Influence of some spice essential oils on Aspetgihs parasiticus and production of aflatoxins in a synthetic medium. Journal of Food Science, 54, 1476. doi:10.1111/j.1365-2621.1989.tb08571.x

Farahani, A., Lebaschi, H., Hussein, M., Shiranirad, A.H., Valadabadi, A.R., Daneshian, J. (2008). Effects of arbuscular mycorrhizal fungi, different levels of phosphorus and drought stress on water use efficiency, relative water content and proline accumulation rate of Coriander (Coriandrum sativum L.). Journal of Medicinal Plants Research, 2, 125-31.

Fester, T., Hause, B., Schmidt, D., Halfmann, K., Schmidt, J., Wray, V., Hause, G., Strack, D. (2002). Occurrence and localization of apocarotenoids in arbuscular mycorrhizal plant roots. Plant Cell Physiology, 43, 256-265. doi:10.1093/pcp/pcf029

Fitter, A.H., Helgason, T., Hodge, A. (2011). Nutritional exchanges in the arbuscular mycorrhizal symbiosis: implications for sustainable agriculture. 
Glomus intraradices (N.C. Schenck \& G.S. Sm, ... essential oil contents and composition in Anethum graveolens L.

Fungal Biology Reviews, 25, 68-72. doi:10.1016/j.fbr.2011.01.002

Freitas, M.S.M., Martins, M.A., Curcino Vieira, I.J., (2004). Yield and quality of essential of Mentha arvensis in response to inoculation with arbuscular mycorrhizal fungi. Pesquisa Agropecuária Brasileira, 39, 887-894. doi:10.1590/S0100204X2004000900008

Geneva, M.P., Stancheva, I.V., Boychinova, M.M., Mincheva, N.H., Yonova, P.A. (2010). Effects of foliar fertilization and arbuscular mycorrhizal colonization on Salvia officinalis L. growth, antioxidant capacity, and essential oil composition. Journal of the Science of Food and Agriculture, 90, 696-702.

Ibrahim, M.H., Jaafar, H.Z.E. (2011). Involvement of carbohydrate, protein and phenylalanine ammonia lyase in up-regulation of secondary metabolites in Labisia pumila under various $\mathrm{CO}_{2}$ and $\mathrm{N}_{2}$ levels. Molecules, $\quad 16, \quad 4172-4190$. doi:10.3390/molecules16054172

Jefferies, P., Gianinazzi, S., Perotto, S., Turnau, K., Barea, J.M. (2003). The contribution of arbuscular mycorrhizal fungi in sustainable maintenance of plant health and soil fertility. Biology and Fertility of Soils, 37, 1-16.

Jones, J.B., Case, V.W. (1990). Sampling, Handling, and Analyzing Plant Tissue Samples. In: Soil Testing and Plant Analysis, Westerman (ed.). Book Series no. 3. Soil Science Society America, Madison WI, pp. 389-427.

Jones, JB Jr. (1972). Plant tissue analysis for micronutrients. p. 319-346. In J.J. Mortvedt, et al. (ed.) Micronutrients in agriculture. Soil Science Society America, Madison, Madison, WI.

Kapoor, R., Chaudhary, V., Bhatnagar. A.K. (2007). Effects of arbuscular and phosphorus application on artemisinin concentration in Artemisia annua L. Mycorrhiza, 17, 581-587. doi:10.1007/s00572-0070135-4

Kapoor, R., Giri, B., Mukerji, K.G. (2002a). Glomus macrocarpum: a potential bioinoculant to improve essential oil quality and concentration in Dill (Anethum graveolens L.) and Carum (Trachyspermum ammi (Linn.) Sprague). World Journal of Microbiology and Biotechnology, 18, 459-463. doi:10.1023/A:1015522100497

Kapoor, R., Giri, B., Mukerji, K.G. (2002b). Mycorrhization of coriander (Coriandrum sativum L) to enhance the concentration and quality of essential oil. Journal of the Science of Food and Agriculture, 82, 339-342. doi:10.1002/jsfa.1039
Kapoor, R., Giri. B., Mukerji, K.G. (2004). Improved growth and essential oil yield and quality in Foeniculum vulgare mill on mycorrhizal inoculation supplemented with P-fertilizer. Bioresource Technology, 93, 307-311. doi:10.1016/j.biortech.2003.10.028

Karagiannidis, N., Thomidis, T., Lazari, D., PanouFilotheou, E., Karagiannidou, C. (2011). Effect of three Greek arbuscular mycorrhizal fungi in improving the growth nutrient concentration, and production of essential oils of oregano and mint plants. Scientia Horticulturae, 129, 329-334. doi:10.1016/j.scienta.2011.03.043

Karasawa, T., Kasahara, Y., Takebe, M. (2002). Differences in growth responses of maize to preceding cropping caused by fluctuation in the population of indigenous arbuscular mycorrhizal fungi. Soil Biology and Biochemistry, 34, 851-857. doi:10.1016/S0038-0717(02)00017-2

Kaschuk, G., Kuyper, T.W., Leffelaar, P.A., Hungria, M., Giller, K.E. (2009). Are the rates of photosynthesis stimulated by the carbon sink strength of rhizobial and arbuscular mycorrhizal symbioses? Soil Biology and Biochemistry, 41, 1233-1244. doi:10.1016/j.soilbio.2009.03.005

Khaliq, A., Sanders, F.E. (2000). Effects of arbuscular mycorrhizal inoculation on the yield and phosphorus uptake of field grown barley. Soil Biology and Biochemistry, 32, 1691-1696. doi:10.1016/S0038-0717(00)00086-9

Khaosaad, T., Vierheilig, H., Ziltterl-Egleer, K., Novak, J. (2006). Arbuscular mycorrhiza alters the concentration of essential oils in oregano (Origanum sp., Lamiaceae). Mycorrhiza, 16, 443446. doi:10.1007/s00572-006-0062-9

Larose, G., Chenevert, R., Moutoglis, P., Gagne, S., Piché, Y., Vierheilig, H. (2002). Flavonoid levels in roots of Medicago sativa are modulated by the developmental stage of the symbiosis and the root colonizing arbuscular mycorrhizal fungus. Journal of Plant Physiology, 159, 1329-1339. doi:10.1078/0176-1617-00896

Lohse, S., Schliemann, W., Ammer, C., Kopka, J., Strack, D., Fester, T. (2005). Organization and metabolism of plastids and mitochondria in arbuscular mycorrhizal roots of Medicago truncatula. Journal of Plant Physiology, 139, 329340. doi:10.1104/pp.105.061457

Loomis, W.D., Corteau, R. (1972). Essential oil biosynthesis. Recent Advances in Phytochemistry, 6, 147-185. doi:10.1016/B978-0-12-612406$4.50012-7$ 
Marschner, H. (1995). Mineral Nutrition of Higher Plants. Academic Press, London.

Mathur, N., Vyas, A. (2000). Influence of arbuscular mycorrhizae on biomass production, nutrient uptake and physiological changes in Ziziphus mauritana Lam. under water stress. Journal of Arid Environments, 45, 191-195. doi:10.1006/jare.2000.0644

McGonigle, T.P., Miller, M.H., Evans, D.G., Fairchild, D.L., Swan, G.A. (1990). A new method which gives an objective measure of colonization of roots by vesicular-arbuscular mycorrhizal fungi. New Phytologist Journals, 115, 495-501. doi:10.1111/j.1469-8137.1990.tb00476.x

Naguib, Y.N., Hussein, M.S., E-Sherbeny, S.E., Khalil, M.Y., Lazari, D. (2007). Response of Ruta graveolens L. to sowing dates and foliar micronutrients. Journal of Applied Sciences Research, 3, 1534-1543.

Nogueira, M.A., Cardoso, E.J.B.N. (2002). Interaccoes microbianas na disponibilidade e absorcao de manganes por soja. Pesquisa Agropecuária Brasileira, 37, 1605-1612. doi:10.1590/S0100204X2002001100012

Pedone-Bonfim, M.V.L., Lins, M.A., Coelho, I.R., Santana, A.S., Silva, F.S.B., Maia, L.C. (2013). Mycorrhizal technology and phosphorus in the production of primary and secondary metabolites in cebil (Anadenanthera colubrina (Vell.) Brenan) seedlings. Journal of the Science of Food and Agriculture, 93, 1479-1484. doi:10.1002/jsfa.5919

Perini, M., Paolini, M., Simoni, M., Bontempo, L., Vrhovšek, U., Sacco, M., Thomas, F., Jamin, E., Hermann, A., Camin, F. (2014). Stable isotope ratio analysis for verifying the authenticity of balsamic and wine vinegar. Journal of Agricultural and Food Chemistry, 62(32), 8197-203. doi:10.1021/jf5013538

Phillips, J.M., Hayman, D.S. (1970). Improved procedures for clearing roots and staining parasitic and vesicular-arbuscular mycorrhizal fungi for rapid assessment of infection. British Mycological Society, 55, 158-161. doi:10.1016/S00071536(70)80110-3

Piccaglia, R., Dellacecca, V., Marotti, M., Giovanelli, E. (1993). Agronomic factors affecting the yields and the essential oil composition of peppermint (Mentha piperita L.). Acta Horticulturae, 344, 2940. doi:10.17660/ActaHortic.1993.344.4

Raei, Y., Weisany, W. (2013). Arbuscular mycorrhizal fungi associated with some aromatic and medicinal plants. Bulletin of Environment, Pharmacology and Life Sciences, 2(11), 129-138.

Rao, A.S., (1993). Analysis of soils for available major nutrients, p. 13-35. In: Tan don HLS (Ed.). Methods of analysis of soils, plants, water and fertilizers development and consultation organization, New Delhi, India.

Richardson, A.E., Lynch, J.P., Ryan, P.R., Delhaize, E., Smith, A., Smith, S.E., Harvey, P.R., Ryan, M.H., Veneklaas, E.J., Lambers, H., Oberson, A., Culvenor, R.A., Simpson, R.J. (2011). Plant and microbial strategies to improve the phosphorus efficiency of agriculture. Plant and Soil, 349, 121156. doi:10.1007/s11104-011-0950-4

Rillig, M.C., Mummey, D.L. (2006). Mycorrhizas and soil structure. New Phytologist, 171, 41-53. doi:10.1111/j.1469-8137.2006.01750.x

Robinson, R.L., Postgate, J.R. (1980). Oxygen and nitrogen in biological nitrogen fixation. Annual Review of Microbiology, 34, 182-207.

SAS Institute Inc. (2004). SAS/STAT user's guide Version 6, fourth ed Statistical Analysis Institute Inc, Cary, North Carolina.

Shende, S., Rai, M. (2010). Role of mycorrhizal fungi in growth promotion of crop. Progress in Mycology. pp 259-292. doi:10.1007/978-90-481-3713-8_9

Simard, W.S., Jones, M.D., Durall, D.M. (2003). Carbon and nutrient fluxes within and between mycorrhizal plants. In: van der Heijden MGA, Sanders IR (eds) Mycorrhizal ecology. Springer, Berlin. doi:10.1007/978-3-540-38364-2_2

Singh, A., Randhawa, G.S. (1990). Studies on some agronomic inputs affecting oil content, oil and herb yield of dill (Anethum graveolens L.). New Botanist, 17, 111-115.

Smith, M. (2003). Therapeutic applications of fenugreek. Alternative Medicine Review, 8, 20-27.

Smith, S. E. and Read, D. J. (2008). Mycorrhizal Symbiosis. 3 rded, Academic Press, London.

Sohrabi, Y., Heidari, G., Weisany, W., Ghasemi Golezani, K., Mohammadi, K. (2012a). Some physiological responses of chickpea (Cicer aritinum L.) cultivars to arbuscular mycorrhiza under drought stress. Russian Journal of Plant Physiology, 59(6), 708-716. doi:10.1134/S1021443712060143

Sohrabi, Y., Heidari, G., Weisany, W., Ghasemi Golezani, K., Mohammadi, K. (2012b). Changes of antioxidativ eenzymes, lipid peroxidation and chlorophyll content in chickpea types colonized by different Glomus species under drought stress. 
Glomus intraradices (N.C. Schenck \& G.S. Sm, ... essential oil contents and composition in Anethum graveolens L.

Symbiosis, 56, 5-18. doi:10.1007/s13199-012-01528

Strack, D., Fester, T. (2006). Isoprenoid metabolism and plastid reorganization in arbuscular mycorrhizal roots. New Phytologist, 172, 22-34. doi:10.1111/j.1469-8137.2006.01837.x

$\mathrm{Su}$, H.C.F., (1985). Laboratory study on effects of Anethum graveolens seed on four species of storedproduct insects. Journal of Economic Entomology, 78, 451-453. doi:10.1093/jee/78.2.451

Subrahmanyam, K., Nair, A.K., Chattopadhyay, A., Singh, D.V. (1992). Evaluation of ammonium polyphosphate as phosphorus source in Japanese mint (Mentha arvensis subsp. haplocalyx var. piperascens). Indian Journal of Agricultural Science, 62, 554-556.

Taiz, L., Zeiger, E. (1998). Plant Physiology, second ed. Sinauer Associates, Inc., Sunderland, Massachusetts.

Tandon, H.L.S., Cescas, M.P., Tyner, E.H. (1968). An acid-free vanadate-molybdate reagent for the determination of total phosphorus in soils. Soil Science Society of America Proceedings, 32, 48-51. doi:10.2136/sssaj1968.03615995003200010012x

Tiwari, R.J., Banafar, R.N.S. (1995). Application of nitrogen and phosphorus increases seed yield and essential oil of coriander. Indian Cocoa, Arecanut and Spices Journal, 19, 51-55.

Torelli, A., Trotta, A., Acerbi, I., Arcidiacono, G., Berta, G., Branca, C. (2000). IAA and ZR content in leek (Allium porrum L.) as influenced by Pnutrition and arbuscular mycorrhizae, in relation to plant development. Plant and Soil, 226, 29-35. doi:10.1023/A:1026430019738

Vierheilig, H., Gagnon, H., Strack, D., Maier, W. (2000b). Accumulation of cyclohexenone derivatives in barley, wheat and maize roots in response to inoculation with different arbuscular mycorrhizal fungi. Mycorrhiza, 9, 291-293. doi:10.1007/PL00009994

Vierheilig, H., Maier, W., Wyss, U., Samson, J., Strack, D., Piché, Y. (2000a). Cyclohexenone derivativeand phosphate-levels in split-root systems and their role in the systemic suppression of mycorrhization in precolonized barley plants. Journal of Plant Physiology, 157, 593-599. doi:10.1016/S01761617(00)80001-2

Vokou, D., Vareltzidou, S., Katinakis, P. (1993). Effects of aromatic plants on potato storage: sprout suppression and antimicrobial activity. Agriculture,
Ecosystems \& Environment, 47, 223- 235. doi:10.1016/0167-8809(93)90124-8

Volpin, H., Eelkind, Y., Okon, Y., Kapulnik, Y. (1994). A vesicular arbuscular mycorrhizal fungus (Glomus intraradix) induces a defense response in alfalfa roots. Plant Physiology, 104, 683-689. doi:10.1104/pp.104.2.683

Walter, M.H., Fester, T., Strack, D. (2000). Arbuscular mycorrhizal fungi induce the non-mevalonate methylerythritol phosphate pathway of isoprenoid biosynthesis correlated with accumulation of the 'yellow pigment' and other apocarotenoids. Plant Journal, $\quad 21, \quad 571-578 . \quad$ doi:10.1046/j.1365313x.2000.00708.x

Weisany, W., Raei, Y., Pertot, I. (2015). Changes in the essential oil yield and composition of dill (Anethum graveolens L.) as response to arbuscular mycorrhiza colonization and cropping system. Industrial Crops and Products, 77, 295-306. doi:10.1016/j.indcrop.2015.09.003

Weisany, W., Raei, Y., Zehtab-Salmasi, S., GhassemiGolezani, K. (2016b). Arbuscular mycorrhizal fungi induced changes in rhizosphere, essential oil and mineral nutrients uptake in dill/common bean intercropping system Funneliformis mosseae improved nutrients uptake of intercropped plants. Annals of Applied Biology, 169, 384-397. doi:10.1111/aab.12309

Weisany, W., Zehtab-Salmasi, S., Raei, Y., Sohrabi, Y., Ghassemi- Golezani, K. (2016a). Can arbuscular mycorrhizal fungi improve competitive ability of dill+common bean intercrops against weeds? European Journal of Agronomy, 75, 60-71. doi:10.1016/j.eja.2016.01.006

Wondimu, T., Afar, Z., Kelbessa, E. (2007). Ethnobotanical study of medicinal plants around 'Dheeraa' town, Arsi Zone, Ethiopia. Journal of Ethnopharmacology, 112, 152-161. doi:10.1016/j.jep.2007.02.014

Yao, M.K., Désilets, H., Charles, M.T., Boulanger, R., Tweddell, R.J. (2003). Effect of mycorrhization on the accumulation of rhishitin and solavetivone in potato plantlets challenged with Rhizoctonia solani. Mycorrhiza, 13, 333-336. doi:10.1007/s00572-0030267-0

Yao, Q., Li, X., Feng, G., Christie, P. (2001). Mobilization of sparingly soluble inorganic phosphates by the external mycelium of an arbuscular mycorrhizal fungus. Plant and Soil, 230, 279-285. doi:10.1023/A:1010367501363 